DOI: https://doi.org/10.53754/iscs.v1i1.5

\title{
ANALISIS KOMPETENSI MENULIS KARYA TULIS ILMIAH MAHASISWA DI INDONESIA
}

\section{ANALYSIS OF STUDENT WRITING COMPETENCY IN INDONESIA}

\author{
Muhammad Heriyudanta \\ Institut Agama Islam Negeri Ponorogo \\ Email:yudanta10@gmail.com
}

\begin{abstract}
This study aimed to determine the competence of writing student scientific papers in Indonesia and the factors that influence it. This research is a type of library research (library research). The data sources that are the study of this research are books, scientific articles from journals, papers, magazines, and so on, which are relevant to this study and can answer the main problem. At the same time, the approach used in this research is philosophical. While the data collection technique used is documentation. In order to direct the accuracy and accuracy of the data under study, the analysis method used is content analysis. The findings of this study indicate that the competence of Indonesian students in writing scientific papers is still very low. In writing, most of them do not heed the guidelines and rules of writing scientific papers, and the level of plagiarism is very high. Based on the research results, in general, the most challenging problems students face in writing scientific papers are difficulties in obtaining references and not knowing writing techniques. Meanwhile, the factors that cause difficulties in writing scientific papers are, for example, low motivation of students in writing, lack of self-confidence and lack of mood, low reading interest, low student curiosity, and students' understanding of scientific writing that is not good as well as low mastery, against his writing conventions.
\end{abstract}

Keywords: Scientific Writing, Students, Writing Competence.

\section{PENDAHULUAN}

Aktivitas menulis bisa dibilang tidak mudah bagi kebanyakan orang. Namun sebaliknya, sebagian orang memiliki anggapan bahwa menulis adalah sesuatu yang mudah dan sangat menyenangkan. Dalam konteks mahasiswa, menulis merupakan hal yang sangat lekat dan penting. Sebab, dalam aktivitas akademik keseharian seorang mahasiswa, keterampilan berbahasa yang satu ini hampir selalu dibutuhkan. Misalnya, ketika setiap hari belajar di ruang-ruang kelas kuliah, bisa dipastikan mereka akan memperoleh tugas menulis makalah dari setiap dosen pengampu mata kuliah. Selain menulis makalah, masih banyak sekali kegiatan menulis yang harus dilakukan dalam perjalanan akademik seorang mahasiswa. Sebut saja menulis hasil penelitian mahasiswa, baik penelitian pustaka, penelitian lapangan maupun penelitian laboratorium. Bahkan, hal yang sangat penting dan dipandang sebagai prasasti yang bisa dijadikan kenang-kenangan seumur hidup bagi mahasiswa sekaligus 
Received: 2021-01-24 Revised: 2021-01-31 Approved: 2021-01-31

sebagai persyaratan memperoleh gelar sarjana, yakni penulisan skripsi, harus dipenuhi melalui aktifitas menulis.

Secara lebih luas, sesungguhnya menulis diperlukan sebagai alat untuk publikasi ilmiah dan menyampaikan pikiran serta gagasan mahasiswa pada saat mereka kuliah maupun ketika kelak mereka sudah terjun di dunia masyarakat, baik itu menjadi ahli (expert) di bidang tertentu, pejabat publik, tokoh masyarakat dan lain sebagainya. Tanpa keterampilan (skill) menulis, mahasiswa akan menjadi manusia yang stagnan, statis, dan tidak bisa mengekspresikan pikirannya. Selain itu, keterampilan menulis karya ilmiah merupakan sarana bagi mahasiswa untuk membiasakan diri dan mengembangkan daya nalarnya secara rasional, kritis, dan objektif. Pendeknya, keterampilan menulis, khususnya menulis karya ilmiah merupakan hal yang tidak dapat dipisahkan dari kegiatan akademis mahasiswa (Lestari, 1999).

Berkaitan dengan hal tersebut, intensitas dan kebiasaan membaca memiliki pengaruh dan peran yang sangat besar dalam menjadikan orang merasasulit dan mudah didalam menulis. Menulis karya ilmiah memang tidak boleh dilakukan secara asal-asalan. Tulisan ilmiah harus ditulis sesuai kaidah atau aturan-aturan penulisan yang bersifat konvensional dan berlaku secara universal. Kaidah dan aturan penulisan tersebut harus ditaati dan diikuti oleh seorang penulis. Misalnya, karya ilmiah akademik adalah contoh dari jenis karya ilmiah yang harus ditulis oleh para siswa, para mahasiswa, dan para karya siswa yang mutlak harus mengikuti aturan dan ketentuan baku yang berlaku dalam penulisan karya ilmiah (Rahardi, 2009).

Karya ilmiah adalah hasil pemikiran ilmiah tentang disiplin ilmu tertentu yang disusun secara sistematis, logis, benar, holistik, dan bertanggung jawab dengan menggunakan bahasa yang baik dan benar. Dari situ bisa dikatakan bahwa pemikiran ilmiah dapat diartikan sebagai karya yang mempunyai prinsip-prinsip ilmiah, berbasis pada telaah ilmu tertentu dan secara metodologi siap dipertanggung jawabkan (Nursalim Dkk., 2007). Penyusunan karya ilmiah harus sistematis supaya pembaca mudah dalam memahaminya. Sistematis di sini berarti urutannya teratur, terarah, mengalir, dan menaati metode penyusunan yang sudah ditentukan.

Pada kenyataannya, seringkali kita dapati banyak mahasiswa diberbagai kampus di Indonesia, yang masih kesulitan untuk menulis dan menganggap menulis karya tulis ilmiah sebagai sesuatu yang sangat sulit bagi para mahasiswa. Hal ini dapat dilihat dari banyaknya mahasiswa yang hanya menyalin dan tempel (copy-paste) karya tulis ilmiah orang yang 
Received: 2021-01-24 Revised: 2021-01-31 Approved: 2021-01-31

sudah dipublikasikan. Publikasi karya tulis ilmiah orang yang seharusnya dibaca, ditelaah, dikembangkan, atau bahkan disanggah, tetapi justru diplagiasi dengan tanpa merasa bersalah sedikitpun. Contoh lain misalnya, bisa dilihat dari minimnya karya tulis mahasiswa yang muncul di media massa dan jurnal, bahkan dalam menulis tugas akhir atau skripsi, mahasiswa masih banyak mengalami kesulitan. Berdasarkan kenyataan di atas, penelitian yang bertujuan untuk menganalisis tentang bagaimana kemampuan menulis karya tulis imiah mahasiswa di Indonesia menjadi penting. Kaitannya dengan itu, peneliti akan meneliti kasus tersebut dengan mengangkat judul “Analisis Kemampuan Menulis Karya Tulis Imiah Mahasiswa Di Indonesia”.

\section{METODE PENELITIAN}

Penelitian ini merupakan penelitian jenis kepustakaan (library research). Penelitian kepustakaan adalah penelitian yang dilakukan dengan cara mengumpulkan data, informasi, dan berbagai macam data-data lainnya yang terdapat dalam kepustakaan (Subagyo, 1991). Sumber data yang menjadi kajian dalam penelitian ini adalah buku-buku, artikel-artikel ilmiah yang bersumber dari jurnal, makalah, majalah dan sebagainya yang relevan dengan kajian ini dan dapat menjawab pokok persoalan. Sementara pendekatan yang digunakan dalam penelitian ini adalah pendekatan filosofis. Pendekatan filosofis digunakan untuk merumuskan secara jelas hakekat yang mendasari konsep-konsep pemikiran (Zubair, 1990). Teknik pengumpulan data yang dilakukan adalah dokumentasi. Teknik dokumentasi adalah metode pengumpulan data yang dilakukan dengan cara mencari data tentang variabel penelitian dari berbagai macam dokumentasi, baik yang berupa catatan, transkip, buku, surat kabar, majalah, jurnal, dan lain sebagainya (Arikunto, 1980). Sedangkan metode analisis data yang digunakan yaitu content analysis. Metode content analysis merupakan sebuah analisis terhadap kandungan isi yang tidak akan lepas dari interpretasi sebuah karya. Secara metodologis, analisis ini mencoba menawarkan asumsi-asumsi epistemologis terhadap pemahaman yang tidak hanya berkutat pada analisa teks tetapi juga menekankan pada konteks yang melingkupinya serta kontekstualisasinya dalam masa yang berbeda (Stempel, 1983) 
Received: 2021-01-24 Revised: 2021-01-31 Approved: 2021-01-31

\section{PEMBAHASAN}

\section{A. Kemampuan Menulis Karya Tulis Imiah Mahasiswa Di Indonesia}

Kemampuan dapat diartikan sebagai sebuah kecakapan, kekuatan, dan kesanggupan. Menurut Tarigan dalam buku Ahmad Susanto, menulis adalah sebuah kegiatan yang ekspresif dan produktif. Dalam menulis, penulis harus terampil dalam memanfaatkan kosa kata, struktur bahasa, dan merangkai kata. Kompetensi menulis ini tidak dimiliki seseorang secara tiba-tiba, namun harus melalui latihan (treatment) dan sering praktik secarateratur. Sementara dalam Kamus Besar Bahasa Indonesia, menulis memiliki arti: (1) membuat huruf (angka dan sebagainya) melalui pena (pensil, spidol, bolfoin, kapur, dan sebagainya); (2) menuangkan pikiran, gagasan atau perasaan (seperti mengarang, membuat surat) melalui tulisan; (3) melukis, menggambar,; dan (4) membatik (kain) membuat cerita, berkirim surat, membuat surat, (Susanto, 2013).

Pengertian lain mengenai menulis dijelaskan oleh Rusyana, yang memiliki pandangan bahwa menulis adalah kompetensi menggunakan pola-pola bahasa dan disampaikan secara tertulis untuk mengekspresikan suatu gagasan/pesan. Sementara dalam perspektif Alwasilah, menulis merupakan kegiatan produktif dalam berbahasa. Sebuah proses psikolinguistik, yang asalnya dengan formasi ide melalui aturan semantik, kemudian didata dengan aturan sintaksis, lalu digelarkan dalam prosedur sistem tulisan (Susanto, 2013). Menurut Saleh Abas, menulis merupakan aktifitas berfikir yang berkelanjutan, mulai dari mencoba sampai dengan kembali mengulas. Menulis juga dapat didefinisikan sebagai aktivitas untuk mengekspresikan ide, gagasan, perasaan, pikiran, kegelisahan, ke dalam lambang-lambang kebahasaan (bahasa tulis) (Abas, 2006).

Kemampuan seseorang dalam menulis ditentukan dari ketepatannya dalam menerapkan setiap unsur bahasa, pengorganisasian ide ke dalam bentuk narasi, ketepatan dalam menerapkan bahasa, dan pemilihan diksi yang akan diambil. Namun terlepas dari itu semua, sesungguhnya kemampuan menulis sangat dipengaruhi oleh intensitas seseorang dalam membaca. Seseorang dengan intesitas membaca yang tinggi akan lebih mudah dalam menulis karena ia paham bagaimana bentuk tulisan yang indah dan baik. Bahkan tidak jarang seseorang akan terpengaruh oleh sumber bacaan yang biasa ia baca.

Fungsi menulis adalah sebagai media untuk komunikasi secara tidak langsung. Dikatakan tidak langsung lantaran tulisan akan berhadapan dengan pihak lain yang membaca, namun hanya menghadapi tulisan. Dalam pandangan Tarigan, fungsi yang paling utama dari tulisan adalah sebagai alat komunikasi tidak langsung. Menulis terbukti sangat penting bagi dunia 
Received: 2021-01-24 Revised: 2021-01-31 Approved: 2021-01-31

pendidikan karena menulis memudahkan para siswa dalam berpikir. Selain itu juga dapat memudahkan kita dalam merasakan dan menikmati hubungan-hubungan, mengasah persepsi dan daya tanggap kita. Sehingga dalam keseharian, kita seringkali menemui apa yang sebenarnya kita pikirkan dan rasakan mengenai orang-orang, masalah-masalah, gagasan, dan berbagai kejadian hanya dalam proses menulis yang aktual (Susanto, 2013).

Berdasarkan pengertian dan penjelasan di atas dapat diambil benang merah bahwa menulis dapat didefinisikan sebagai kemampuan atau kompetensi seseorang untuk melukiskan lambang grafis yang dimengerti oleh penulis sekaligus pembaca ke dalam tulisan, untuk menyampaikan gagasan, pikiran, kehendak, perasaan, agar dapat dipahami oleh pembaca. Dari penjelasan tersebut dapat dikatakan bahwa menulis merupakan salah satu bagian terpenting dalam kehidupan keseharian. Sehingga pengajaran menulis harus benar-benar diperhatikan secara serius dalam kegiatan pembelajaran bahasa Indonesia di sekolah.

Dalam konteks kompetensi menulis mahasiswa Indonesia, ternyata banyak data dan informasi yang mengatakan bahwa kemampuan menulis karya tulis ilmiah mahasiswa masih sangat rendah, aturan penulisan karya tulis ilmiah tidak mengindahkan pedoman, ditambah dengan tingkat plagiarisme sangat tinggi. (Arif Widodo, Abdul Kadir Jaelani, Setiani Novitasari, Deni Sutisna, 2020). Sekarang ini, realitanya memang budaya menulis karya tulis ilmiah pada kalangan mahasiswa di Indonesia bisa dibilang masih sangat rendah rendah. Hal tersebut bisa dilihat dari minimnya mahasiswa Indonesia yang melakukan publikasi karya ilmiah. Nature Publishing Index Asia Pasific (badan penerbit jurnal ilmiah seluruh Asia Pasifik) mengeluarkan daftar publikasi karya ilmiah (pada rentang tanggal 14 April 2014 s.d. 13 April 2015, menempatkan Indonesia berada diurutan ke-12 dari 20 negara se Asia Pasifik (Persadha, 2016). Hasil penelitian-penelitan yang mencoba ingin mengetahui kemampuan menulis karya tulis ilmiah di berbagai kampus Indonesia, rata-rata menunjukkan bahwa mahasiswa Indonesia memang belum memiliki kemampuan yang ideal dalam penulisan karya tulis ilmiah.

\section{B. Faktor-Faktor Yang Mempengaruhi Kemampuan Menulis Karya Tulis IImiah Mahasiswa Di Indonesia}

Berdasarkan hasil penelitian yang dilakukan, secara umum, kesulitan yang paling dihadapi oleh mahasiswa dalam menulis karya tulis ilmiah adalah kesulitan dalam memperoleh referensi dan tidak mengetahui teknik menulis. Sementara faktor-faktor yang menyebabkan kesulitan dalam menulis karya tulis ilmiah adalah misalnya rendahnya motivasi mahasiswa 
Received: 2021-01-24 Revised: 2021-01-31 Approved: 2021-01-31

dalam menulis, kurang percaya diri dan kurang mood, minat baca yang rendah, keingintahuan mahasiswa yang rendah, dan pemahaman mahasiswa mengenai karya tulis ilmiah yang kurang baik sekaligus rendahnya penguasaan terhadap kaidah-kaidah penulisannya.

Pertama, rendahnya motivasi di dalam diri mahasiswa, sehingga pada gilirannya muncul rasa malas untuk menulis. Agaknya faktor penghambat ini menjadi salah satu tema sentral yang diangkat responden. Secara umum responden dari interview dan focus group discussion mengatakan bahwa kesulitan dihadapi mereka dari dalam adalah rasa malas untuk menulis itu sendiri. Walaupun rasa malas yang kecil, itupun sudah menjadi pemicu munculnya rasa malas dalam dirinya, apalagi jika rasa malasnya besar, hampir bisa dipastikan untuk tidak akan menulis.

Kedua, tidak hanya rasa malas, kurang percaya diri dan tidak ada mood (badmood) ternyata juga memiliki pengaruh besar dalam menghambat dalam melakukan suatu kegiatan menulis yang banyak dikemukakan oleh responden. Rasa malas dan kurang percaya diri dan tidak ada mood (badmood) sepertinya merupakan satu kesatuan yang ada dalam diri mahasiswa sebagai akibat dari rendahnya motivasi dalam diri mereka, sehingga upaya untuk melakuakan kegiatan menulis tidak menjadi sesuatu yang diprioritaskan (Sutanto, 2010). mahasiswa sebagai bagian dari kampus, seyogyanya memperoleh dukungan dari civitas akademika untuk menyelesaikan masalahnya. Hal ini merupakan salah satu bagi seluruh civitas akademika, terutama pihak dosen, agar dapat memotivasi mahasiswa dan mahasiswa dapat menghasilkan karya tulis ilmiah yang unggul. Kompetensi dosen yang tinggi diharapkan dapat menolong mahasiswa untuk keluar dari proble internal tersebut.

Ketiga, minat baca dan rasa ingin tahu (curiosity) yang rendah. Data Bank Dunia tahun 1998 (Sutini, 2010) menginformasikan bahwa kebiasaan membaca anak-anak Indonesia berada pada level paling rendah (nilai 51,7). Nilai tersebut di bawah Filipina $(52,6)$, Thailand $(65,1)$, dan Singapura $(74,0)$. Begitu pula Riset International Association for Evaluation of Educational Achievement (IAEEA) tahun 1996 menyebutkan bahwa kemampuan membaca usia 9-14 tahun Indonesia berada pada urutan ke-41 dari 49 negara yang disurvei. Selain itu, ditambahkan dari data Siswati, (Siswati, 2010) bahwa publikasi IAEEA tanggal 28 November 2007 tentang minat baca dari 41 negara menginformasikan kemampuan membaca masyarakat Indonesia selevel dengan negara belahan bagian selatan Selandia Baru dan Afrika Selatan. Sedangkan BPS tahun 2006 mempublikasikan, membaca bagi masyarakat Indonesia belum menjadikan kegaiatan sebagai sumber untuk mendapatkan 
Received: 2021-01-24 Revised: 2021-01-31 Approved: 2021-01-31

informasi. Ditemukan masyarakat cenderung lebih memilih menonton televisi $(85,9 \%)$ dan mendengarkan radio (40,3\%) daripada membaca $(23,5 \%)$. Artinya, membaca untuk mendapatkan informasi baru dilakukan oleh 23,5\% dari total penduduk Indonesia. Dengan data ini terbukti bahwa membaca belum menjadi kebutuhan bagi masyarakat (Siregar, 2018). Diakui atau tidak, sesungguhnya minat baca dan rasa ingin tahu yang tinggi memiliki pengaruh yang sangat besar keterampilan menulis seseorang. Hal ini disampaikan oleh beberapa penulis-penulis hebat seperti Asma Nadia, Aidh Al-Qarni, Henry G. Tarigan, dan sebagainya.

Keempat, faktor penghambat kemampuan menulis mahasiswa selanjutnya adalah rendahnya pemahaman mahasiswa mengenai karya tulis ilmiah yang kurang baik sekaligus rendahnya penguasaan terhadap kaidah-kaidah penulisannya. Rata-rata mahasiswa di Indonesia masih kurang memahami kaidah penulisan karya ilmiah. Karena tidak mengetahui dan tidak memahami apa yang akan dilakukan dalam kegiatan tersebut, pada gilirannya mereka menjadi malas untuk mencari bahan referensi agar bisa menemukan ide, kemudian karena tidak punya ide maka sulit untuk memulai (Sutanto, 2010)

\section{KESIMPULAN}

Menulis dapat didefinisikan sebagai kemampuan atau kompetensi seseorang untuk melukiskan lambang grafis yang dimengerti oleh penulis sekaligus pembaca ke dalam tulisan, untuk menyampaikan gagasan, pikiran, kehendak, perasaan, agar dapat dipahami oleh pembaca. Sedangkan karya tulis ilmiah adalah hasil pemikiran ilmiah tentang disiplin ilmu tertentu yang disusun secara sistematis, logis, benar, holistik, dan bertanggung jawab dengan menggunakan bahasa yang baik dan benar

Dalam konteks kompetensi menulis karya tulis ilmiah mahasiswa Indonesia, ternyata banyak informasi yang mengatakan bahwa kemampuan menulis karya tulis ilmiah mahasiswa masih sangat rendah, aturan penulisan karya tulis ilmiah tidak mengindahkan pedoman, ditambah dengan tingkat plagiarisme sangat tinggi. Sekarang ini, realitanya memang budaya menulis karya tulis ilmiah pada kalangan mahasiswa di Indonesia bisa dibilang masih sangat rendah rendah. Hal tersebut bisa dilihat dari minimnya mahasiswa Indonesia yang melakukan publikasi karya ilmiah. Nature Publishing Index Asia Pasific (badan penerbit jurnal ilmiah seluruh Asia Pasifik) mengeluarkan daftar publikasi karya ilmiah (pada rentang tanggal 14 April 2014 s.d. 13 April 2015, menempatkan Indonesia berada diurutan ke-12 dari 20 negara 
Received: 2021-01-24 Revised: 2021-01-31 Approved: 2021-01-31

se Asia Pasifik (Persadha, 2016). Hasil penelitian-penelitan yang mencoba ingin mengetahui kemampuan menulis karya tulis ilmiah di berbagai kampus Indonesia, rata-rata menunjukkan bahwa mahasiswa Indonesia memang belum memiliki kemampuan yang ideal dalam penulisan karya tulis ilmiah.

Berdasarkan hasil penelitian yang dilakukan, secara umum, kesulitan yang paling dihadapi oleh mahasiswa dalam menulis karya tulis ilmiah adalah kesulitan dalam memperoleh referensi dan tidak mengetahui teknik menulis. Sementara faktor-faktor yang menyebabkan kesulitan dalam menulis karya tulis ilmiah adalah misalnya rendahnya motivasi mahasiswa dalam menulis, minat baca yang rendah, keingintahuan mahasiswa yang rendah, dan instruksi menulis yang tidak jelas.

\section{DAFTAR PUSTAKA}

Abas, S. (2006) Pembelajaran Bahasa Indonesia Yang Aktif Di Sekolah Dasar. Jakarta: Depdiknas. Arif Widodo, Abdul Kadir Jaelani, Setiani Novitasari, Deni Sutisna, M. E. (2020) 'ANALISIS KEMAMPUAN MENULIS MAKALAH MAHASISWA BARU PGSD UNIVERSITAS MATARAM', Didika: Wahana Ilmiah Pendidikan Dasar, 6(1).

Arikunto, S. (1980) Prosedur Penelitian: Suatu Pendekatan Praktek. Jakarta: Bina Usaha.

Dkk., M. N. (2007) Psikologi Pendidikan. Surabaya: Unesa. University Press.

Lestari, A. W. dan L. A. (1999) Menulis. Karya Ilmiah. Surabaya: Airlangga.

Persadha, D. A. K. (2016) 'Studi Kompetensi Kemampuan Menulis di Kalangan Mahasiswaa', $M U A D D I B, 6(1)$.

Rahardi, K. (2009) Sosiopragmatik. Jakarta: Erlangga.

Siregar, N. A. dan A. (2018) 'FAKTOR-FAKTOR YANG MEMPENGARUHI LITERASI MEMBACA BAHASA INDONESIA YANG BERKEMAJUAN', Prosiding Pekan Seminar Nasional (Pesona).

Siswati (2010) 'Minat Membaca Pada Mahasiswa (Studi Deskriptif Pada Mahasiswa Fakultas Psikologi)', Jurnal Psikologi UNDIP, 8(2).

Stempel, G. H. (1983) Content Analysis. Edited by terj. J. R. dan A. Kasta. Bandung: Arai Komunikasi.

Subagyo, J. (1991) Metode Penelitian dan Praktek. Jakarta: Rhineka Cipta.

Susanto, A. (2013) Teori Belajar Dan Pembelajaran Di Sekolah Dasar. Jakarta: Kencana Prenada Media Group.

Sutanto, L. (2010) Kiat Jitu Menulis dan Menerbitkan Buku. Jakarta: Erlangga. 
Received: 2021-01-24 Revised: 2021-01-31 Approved: 2021-01-31

Sutini (2010) 'Upaya Meningkatkan Minat Baca Siswa Kelas III Sekolah Dasar', Jurnal Kependidikan Interaksi, 5(5).

Zubair, A. B. dan A. C. (1990) Metodologi Penelitian Filsafat. Yogyakarta: Kanisius.

\section{Copyright (c) 2021 Muhammad Heriyudanta}

cc) (7) (8) This work is licensed under a Creative Commons Attribution-NonCommercial 4.0

EY NG International License. 